\title{
PENINGKATAN KEMAMPUAN PEMAHAMAN DAN KOMUNIKASI MATEMATIS SISWA SMK MELALUI PEMBELAJARAN KONSTRUKTIVISME MODEL NEEDHAM
}

\author{
NIA GARDENIA \\ niagardenia@ymail.com \\ Program Studi Pendidikan Matematika, Fakultas Teknik, Matematika, dan IPA \\ Universitas Indraprasta PGRI
}

\begin{abstract}
This study aims to determine the attainment and increase the ability of understanding and communication students' mathematical vocational high school (SMK) through learning by using constructivist Needham Model. This research is a quasi experiment desaign with a control group of non equivalence using purposive sampling technique. The population in this study were all students of class X SMK Pajajaran Bandung scattered in 6 classes, and that the research sample are as many as two classes. Of the two classified into two groups, the group learning by using Needham and conventional models. Class X PM used as the experiment group, while X AP classes serve as a control group. The data were analyze quantitative and quanlitative. Quantitative analysis was performed by using t test, t' test, Mann-Whitney U test. Qualitative analysis was conducted to determine the attitude of the students after getting a constructivism learning of Needham Model. Data collected through the test and attitude scale. The results showed that, (1) Improving the ability of mathematical understanding of students who get teaching Needham Model better than students who received conventional learning, (2) Increasing the capability of mathematical communication students who has learning with Needam Model better than students who received conventional learning, (3) in general, students showed a positive attitude towards learning mathematics, problems and communication as well as to study of mathematics that uses Needham Models
\end{abstract}

Keywords: Constructivism Learning, Needham Model, The ability of mathematical understanding, mathematical communication skills.

\section{PENDAHULUAN}

Dunia pendidikan merupakan sesuatu yang dinamis, sehingga senantiasa harus tanggap dalam menghadapi dan mengantisipasi setiap perubahan globalisasi yang terjadi. Dalam iklim globalisasi, kita dituntut untuk memiliki kemampuan bersaing, mampu bekerja sama, gesit, cerdas, disiplin, jujur, dan hemat. Karakter semacam ini akan berakar pada diri siswa selaku generasi penerus bangsa diantaranya melalui pembelajaran matematika, sebab belajar matematika akan membentuk kemampuan bernalar pada diri siswa yang tercemin melalui kemampuan berfikir kritis, logis, sistematis, dan mempunyai sifat jujur, disiplin dalam memecahkan suatu permasalahan baik dalam bidang matematika, bidang lain maupun dalam kehidupan sehari-hari. Pada kenyataanya, selalu ada hambatan dalam pembelajaran matematika itu sendiri salah satunya matematika dianggap sebagai pelajaran yang sulit. Orang yang berkepentingan dengan matematika, walaupun matematika dikenal sebagai ilmu yang sukar dipahami, akan mencari cara terbaik bagaimana mempelajari bidang tersebut.

Berdasarkan tujuan pembelajaran matematika yang hendak dicapai, kemampuan pemahaman konsep menjadi kompetensi yang esensial dan merupakan visi dari belajar matematika. Hal ini dipertegas dalam NCTM (2000) yang menyatakan bahwa peserta didik dalam belajar matematika harus disertai dengan pemahaman. Berkaitan dengan 
pentingnya pemahaman dalam matematika, Sumarmo (2003) menyatakan bahwa kemampuan pemahaman matematis penting dimiliki siswa karena diperlukan untuk menyelesaikan masalah matematika, masalah dalam disiplin ilmu lain, dan masalah dalam kehidupan sehari-hari, yang merupakan visi pengembangan pembelajaran matematika untuk memenuhi kebutuhan masa kini.Siswa dikatakan memahami ketika mereka sudah dapat menyatakan situasi-gambar-diagram ke dalam bahasa, simbol, ide, model matematika; menjelaskan ide, situasi, dan relasi matematis secara lisan atau tulisan; mendengarkan, berdiskusi, presentasi, menulis matematika; membaca representasi matematis; dan mengungkapkan kembali suatu uraian matematis dengan bahasa sendiri.

Pemahaman matematis erat kaitannya dengan komunikasi matematis (mathematical communication). Siswa yang sudah mempunyai kemampuan pemahaman matematis dituntut untuk dapat mengkomunikasikannya, agar pemahamannya bisa dimanfaatkan oleh orang lain, dengan mengkomunikasikan ide-ide matematisnya kepada orang lain, siswa bisa meningkatkan pemahaman matematisnya. Hal ini serupa dengan pandangan Huggins (Qohar, 2010) bahwa untuk meningkatkan pemahaman konseptual matematis, peserta didik melakukannya dengan mengemukakan ide-ide matematisnya.

Pentingnya menumbuh kembangkan kemampuan komunikasi matematis juga dikemukakan oleh Greenes dan Schulman (Ansari, 2003) bahwa komunikasi merupakan: (a) kekuatan bagi siswa dalam merumuskan konsep dan strategi dalam matematika; (b) sebagai modal keberhasilan siswa terhadap pendekatan dan penyelesaian dalam eksplorasi dan investigasi dalam matematika; dan (c) sebagai wadah bagi siswa untuk berkomunikasi dengan teman, untuk memperoleh informasi, bertukar pikiran dan penemuan, curah pendapat, menilai dan mempertanyakan ide untuk meyakinkan orang lain.

Pada kenyataannya kemampuan pemahaman dan komunikasi matematis siswa Indonesia belum sepenuhnya baik. Hal ini ditunjukkan dari hasil penelitian TIMSS 2011, Indonesia menempati peringkat ke 38 dari 63 negara dalam pembelajaran matematika. Aspek yang dinilai dalam matematika adalah pengetahuan tentang fakta, prosedur, konsep, penerapan pengetahuan dan pemahaman konsep. Menurut laporan hasil studi tersebut, hanya $28 \%$ siswa Indonesia yang menjawab benar, sedangkan rata-rata internasional $47 \%$. Jika dibandingkan dengan negara lain kemampuan Indonesia dalam menerjemahkan soal ke dalam bahasa atau ide matematika diagram atau grafik ini masih berada di bawah rata-rata (TIMSS, 2011).

Sementara itu, hasil laporan survei Programme for International Student Assessment (PISA) yang merupakan program organisasi kerjasama ekonomi dan pembangunan dunia (OECD) menunjukkan bahwa pada tahun 2009, prestasi siswa Indonesia berada pada posisi 68 dari 74 negara yang disurvei. Skor rata-rata kemampuan matematis siswa Indonesia yaitu 371 di bawah skor rata-rata kemampuan matematis siswa di negara lainnya yaitu 496 Aspek yang dinilai dalam PISA adalah kemampuan pemahaman, pemecahan masalah (problem solving), kemampuan penalaran (reasoning), dan kemampuan komunikasi (communication).

Hasil TIMSS dan PISA tersebut dapat dijadikan sebagai salah satu informasi bahwa masih banyak siswa yang belum bisa menjawab soal-soal yang tidak rutin, itu dikarenakan siswa hanya terbiasa mengerjakan soal yang bersifat prosedural dan rutin bukan soal yang memerlukan pemahaman dan komunikasi matematis. Padahal materimateri matematika yang diajarkan kepada siswa seharusnya bukan sekadar hafalan,namun harus yang menuntut pemahaman dan komunikasi. Selain meneliti kemampuan pemahaman dan komunikasi matematis siswa, peneliti juga akan mengungkap sikap dan karakter siswa dalam belajar matematika. Demikian halnya dengan materi yang diberikan 
akan lebih mudah dipahami bila siswa mempunyai sikap yang positif terhadap mata pelajaran matematika.

Berdasarkan pemaparan dan data di atas menunjukkan bahwa kemampuan pemahaman dan komunikasi matematis masih rendah. Pembelajaran matematika yang baik tentunya dapat meningkatkan kemampuan tersebut. Salah satu model pembelajaran yang diduga dan dapat menjadi alternatif pembelajaran matematika untuk meningkatkan kemampuan pemahaman dan komunikasi salah satunya adalah pembelajaran konstruktivisme model Needham.

Nair (2005) menjelaskan pembelajaran konstruktivisme model Needham adalah sebuah model pembelajaran yang menyajikan pembelajaran dengan tahapan-tahapan yang terstruktur. Tahapan-tahapan tersebut diantaranya: orientasi, pencetusan ide, penstrukturan semula ide, penggunaan ide, dan refleksi. Pada model pembelajaran ini siswa pada awalnya dikondisikan untuk menimbulkan minat belajar, kemudian menyajikan hal baru dengan cara yang menarik. Setelah itu siswa dibawa untuk mengingat kembali ide-ide dan konsep sebelumnya untuk masuk ke pengetahuan baru, pada tahap ini kemampuan pemahaman matematis siswa sangat dibutuhkan dan dikembangkan, sebab dalam mengingat dan mengaitkan ide baru tentunya membutuhkan pemahaman. Setelah tahap pencetusan ide, siswa dituntut untuk menjabarkan ide-ide mereka secara individu maupun berkelompok dan membina pengetahuan mereka sendiri secara lebih bermakna. Pada tahap ini, kemampuan komunikasi yang akan terlihat pada siswa pada saat siswa melakukan modifikasi atau penyususnan ide-ide secara berurutan. Pada tahap penggunaan ide, kemampuan pemahaman matematis pun dibutuhkan karena pada tahap ini siswa mengaplikasikan pengetahuan yang sudah didapat untuk menyelesaikan masalah dalam situasi baru. Pembelajaran konstruktivisme model Needham ini terlihat pada setiap tahapannya menuntut pemahaman dan komunikasi matematis, sehingga dengan model ini diharapkan pemahaman dan komunikasi matematis siswa diduga akan meningkat. Dari pemaparan di atas maka penulis tertarik mengadakan penelitian masalah Peningkatan Kemampuan Pemahaman dan Komunikasi Matematis Siwa SMK melalui Pembelajaran Konstruktivisme Model Needham.Penelitian ini bertujuan untuk mengetahui: 1. Peningkatan kemampuan pemahaman matematis siswa yang memperoleh pembelajaran konstruktivisme model Needham lebih baik daripada siswa yang memperoleh pembelajaran secara konvensional, 2. Peningkatan kemampuan komunikasi matematis siswa yang memperoleh pembelajaran konstruktivisme model Needham lebih baik daripada kemampuan siswa yang memperoleh pembelajaran secara konvensional, 3. Sikap siswa terhadap pembelajaran matematika dengan konstruktivisme model Needham.

\section{TINJAUAN PUSTAKA}

\section{Pemahaman Matematis}

Menurut Sumarmo (1987) pemahaman merupakan terjemahan dari istilah understanding yang diartikan sebagai penyerapan arti suatu materi yang dipelajari. Pemahaman merupakan salah satu aspek dalam Taksonomi Bloom. Untuk memahami suatu objek secara mendalam seseorang harus mengetahui: 1) objek itu sendiri, 2) relasinya dengan objek lain yang sejenis, 3) relasinya dengan objek lain yang tidak sejenis, 4) relasi-dual dengan objek lainnya yang sejenis, 5) relasi dengan objek dalam teori lainnya.

\section{Komunikasi Matematis}

NCTM (1989) mengemukakan bahwa standar kurikulum matematika sebagai alat komunikasi matematis lebih ditekankan pada kemampuan siswa dalam hal: (1) 
mengungkapkan dan menjelaskan pemikiran mereka tentang ide matematika dan hubungannya; (2) merumuskan definisi matematis dan membuat generalisasi yang diperoleh melalui investigasi; (3) mengungkapkan ide matematis secara lisan dan tulisan; (4) menyajikan matematika yang dibaca dan ditulis dengan pengertian; (5) menjelaskan dan mengajukan pertanyaan yang dihubungkan pada matematika yang pernah mereka baca atau dengar; (6) menghargai nilai ekonomis, kekuatan, keindahan notasi matematika, serta peranannya dalam mengembangkan ide/gagasan matematis.

\section{Pembelajaran Konstruktivisme Model Needham}

Needham merumuskan lima fase pembelajaran sebagai berikut:

1. Fase Orientasi

Fase ini bertujuan untuk menarik dan perhatian siswa serta memotivasi siswa agar mereka terus menerus berminat dalam pembelajaran yang berlangsung.

2. Fase Pencetusan Ide

Dalam fase ini perlu ditekankan adanya aktivitas seperti perbincangan dalam kelompok diskusi kecil, membuat penggabungan antara pengetahuan awal siswa dengan pengetahuan baru yang diperolehnya.

3. Fase Penstrukturan Ide

Dalam fase ini, guru memberikan kegiatan tugas terstruktur untuk ide awal mereka dan menstruktur ulang dengan pengetahuan yang baru dari hasil diskusi yang dilakukan pada fase pencetusan ide.

4. Fase Aplikasi

Dalam fase ini, siswa mengaplikasikan pengetahuan baru dengan menyelesaikan beberapa permasalahan yang diajukan oleh guru untuk dibahas bersama oleh peserta didik dan teman-temannya.

5. Fase Refleksi

Fase ini adalah fase terakhir dari Needham dimana guru mulai mengajukan pertanyaan kepada peserta didik untuk mengukur tingkat pengetahuan dan pemahaman siswa yang diperolehnya.

\section{Sikap Siswa}

Menurut Osgood (Fitria: 2011) sikap merupakan bentuk evaluasi atau reaksi perasaan.Menurut ilmu psikologi sikap merupakan pola reaksi individu terhadap sesuatu stimulus yang berasal dari lingkungan.

\section{METODE}

Desain kuasi-eksperimen dari penelitian ini adalah sebagai berikut:

$\begin{array}{llll}\text { Kelas Eksperimen } & : \mathrm{O} & \mathrm{X} & \mathrm{O} \\ \text { Kelas Kontrol } & : \mathrm{O}^{--} & - & \mathrm{O}\end{array}$

Di mana: $\quad \mathrm{X} \quad$ : Pembelajaran Konstruktivisme Model Needham

$\mathrm{O}$ : Pemberian Pretes dan Postes

- - - : Subjek tidak dikelompokkan secara acak

\section{Populasi, Sampel, dan Teknik Pengambilan Sampel}

Penelitian ini dilakukan di SMK Pajajaran Bandung. Populasi dalam penelitian ini adalah seluruh siswa kelas $\mathrm{X}$ dengan sampel penelitian terdiri dari dua kelas, satu kelas sebagai kelas eksperimen dan kelas yang lainnya sebagai kelas kontrol. Penentuan sampel pada penelitian ini tidak memungkinkan secara acak murni. Oleh karena itu, sampling yang mungkin dilakukan adalah 'purposive Sampling' sampel dipilih secara sengaja dengan pertimbangan tertentu (Sugiyono, 2008). 


\section{Teknik Analisis}

Data yang diperoleh dari hasil tes kemampuan pemahaman dan komunikasi matematis diolah melalui tahapan sebagai berikut:

1) Mengolah data pretes dan postes kelas eksperimen dan kontrol untuk mengetahui kesamaan kemampuan pemahaman dan komunikasi matematis siswa dengan menggunakan uji t, uji $\mathrm{t}^{\prime}$, uji Mann-Whitney.

2) Menentukan skor peningkatan kemampuan pemahaman dan komunikasi matematis dengan rumus $\mathrm{N}$-gain ternormalisasi

\section{HASIL DAN PEMBAHASAN}

\section{Hasil Penelitian Kemampuan Pemahaman Matematis}

Data tes kemampuan pemahaman matematis diperoleh dari 62 orang siswa, terdiri dari 31 siswa kelas eksperimen yang mendapat pembelajaran konstruktivisme model Needham dan 31 siswa kelas kontrol yang mendapat pembelajaran konvensional.

\section{Deskripsi Statistik Data Hasil Tes Kemampuan Pemahaman Matematis}

Tabel 1. Deskripsi Rataan Pretes dan Postes

Kemampuan Pemahaman Matematis Setiap Indikator

\begin{tabular}{cccccc}
\hline & Kelas & \multicolumn{2}{c}{ Needham } & \multicolumn{2}{c}{ Konvensional } \\
& Data & Pretes & Postes & Pretes & Postes \\
\hline Rataan & Mengingat dan menerapkan sesuatu secara & 0,45 & 1,58 & 0,45 & 1,42 \\
Kemampuan & rutin atau perhitungan sederhana (skor $=3)$ & $(15 \%)$ & $(52,67 \%)$ & $(15 \%)$ & $(48,33 \%)$ \\
Pemahaman & Dapat mencobakan sesuatu dalam kasus & 1,58 & 4,94 & 1,45 & 4,71 \\
Matematis & sederhana dan tahu bahwa kasus itu berlaku & $(26 \%)$ & $(82,33 \%)$ & $(24,17 \%)$ & $(78,5 \%)$ \\
& dalam kasus serupa(skor = 6) & & & \\
& Dapat membuktikan kebenaran sesuatu(skor $=$ & 0,9 & 2,54 & 1 & 1,97 \\
& $3)$ & $(30 \%)$ & $(84,67 \%)$ & $(33,33 \%)$ & $(65,67 \%)$ \\
\hline
\end{tabular}

Analisis Data Peningkatan Kemampuan Pemahaman Matematis

Tabel 2. Rataan Klasifikasi N-gain

Kemampuan Pemahaman Matematis

\begin{tabular}{|c|c|c|}
\hline Kelas & Mean & Klasifikasi \\
\hline Konvensional & 0,5861 & Sedang \\
\hline Needham & 0,6868 & Sedang \\
\hline
\end{tabular}

Tabel 3. Uji Normalitas Skor N-gain

\begin{tabular}{|c|c|c|c|c|}
\hline \multirow{2}{*}{ Kelas } & \multicolumn{3}{|c|}{ Shapiro-Wilk } & \multirow{2}{*}{ Kesimpulan } \\
\cline { 2 - 4 } & Statistic & Df & Sig. & Data Berdistribusi Normal \\
\hline Needham & 0,959 & 31 & 0,279 & Dat \\
\hline Konvensional & 0,947 & 31 & 0,126 & Data Berdistribusi Normal \\
\hline
\end{tabular}

Tabel 4. Uji Homogenitas Varians Skor N-gain Kemampuan Pemahaman matematis

\begin{tabular}{|c|c|c|c|c|}
\hline $\begin{array}{c}\text { Levene } \\
\text { Statistic }\end{array}$ & $d f 1$ & $d f 2$ & Sig. & Kesimpulan \\
\hline 1,270 & 1 & 60 & 0,264 & Variansi homogen \\
\hline
\end{tabular}


Tabel 5. Uji Perbedaan Rataan Skor N-gain

Kemampuan Pemahaman Matematis

\begin{tabular}{|c|c|c|c|}
\hline \multicolumn{3}{|c|}{$\boldsymbol{t}$-test for Equality of Means } & \multirow{2}{*}{ Keterangan } \\
\hline $\boldsymbol{T}$ & $\boldsymbol{D f}$ & Sig. (2-tailed) & \\
\hline 1,949 & 60 & 0,056 & $\mathrm{H}_{0}$ Ditolak \\
\hline
\end{tabular}

Deskripsi Statistik Data Hasil Tes Kemampuan Pemahaman Matematis

Tabel 6

Deskripsi Rataan Pretes dan Postes

Kemampuan Komunikasi Matematis Setiap Indikator

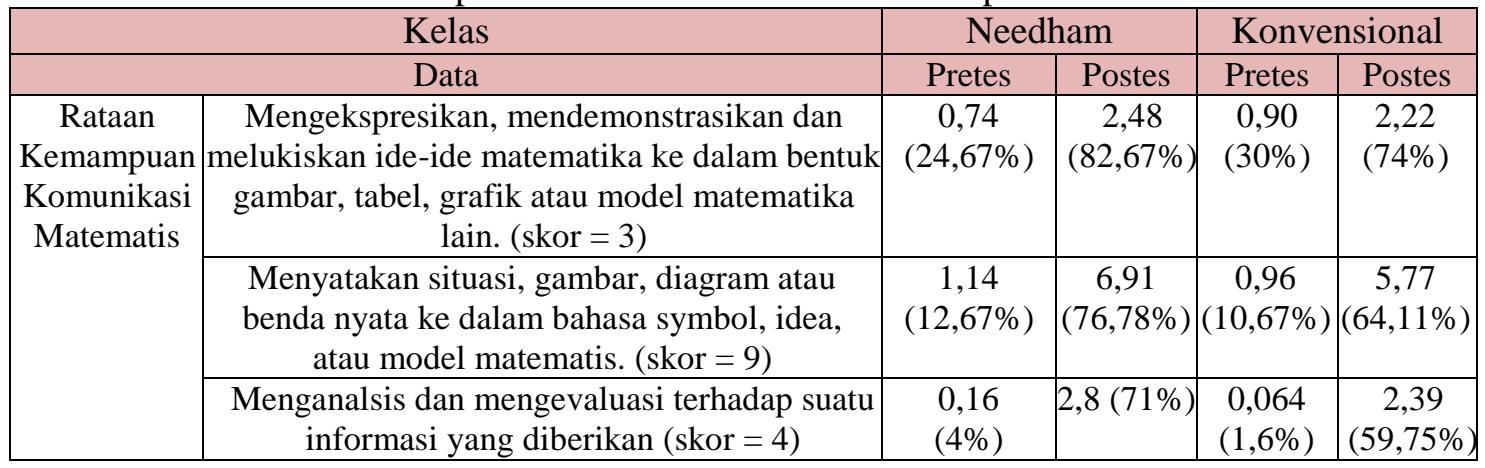

Analisis Data Peningkatan Kemampuan Pemahaman Matematis

Tabel 7. Rataan Klasifikasi N-gain

Kemampuan Komunikasi Matematis

\begin{tabular}{|c|c|c|}
\hline Kelas & Mean & Klasifikasi \\
\hline Kontrol & 0,81 & Tinggi \\
\hline Eksperimen & 1 & Tinggi \\
\hline
\end{tabular}

Tabel 8. Uji Normalitas Skor N-gain

Kemampuan Komunikasi Matematis

\begin{tabular}{|c|c|c|c|c|}
\hline \multirow{2}{*}{ Kelas } & \multicolumn{3}{|c|}{ Shapiro-Wilk } & \multirow{2}{*}{ Kesimpulan } \\
\cline { 2 - 4 } & Statistic & $\boldsymbol{D f}$ & Sig. & Tidak Berdistribusi Normal \\
\hline Needham & 0,907 & 31 & 0,011 & Tidak Berdistribusi Normal \\
\hline Konvensional & 0,962 & 31 & 0,032 & \\
\hline
\end{tabular}

Tabel 9. Uji Perbedaan Rataan Skor N-gain

Kemampuan Komunikasi Matematis

\begin{tabular}{|l|c|c|}
\hline \multicolumn{1}{|c|}{ Statistik } & Nilai & Keterangan \\
\cline { 1 - 2 } Mann-Whitney U & 343,000 & \multirow{2}{*}{$\mathrm{H}_{0}$ Ditolak } \\
\hline Z & $-1,939$ & \\
\hline Asymp. Sig. (2-tailed) & 0,007 & \\
\hline
\end{tabular}

Analisis Angket

Skala Sikap Siswa

Skala sikap yang diberikan pada kelas eksperimen bertujuan untuk mengetahui pendapat siswa terhadap pembelajaran kontruktivisme model Needham. Model skala sikap yang digunakan adalah model Likert. Skala sikap terdiri dari 20 butir pernyataan. 


\section{Pembahasan}

\section{Peningkatan Kemampuan Pemahaman Matematis}

Berdasarkan hasil penelitian yang sudah diuraikan sebelumnya diperoleh hasil bahwa pembelajaran konstruktivisme model Needham dapat meningkatkan kemampuan pemahaman matematis. Hasil tersebut memberikan gambaran bahwa pembelajaran model Needham yang dialami oleh siswa berkontribusi terhadap cara berpikir siswa. Selain itu dari ke-tiga indikator pemahaman matematis yang diteliti dalam pembelajaran model Needhamdan pembelajaran konvensional terdapat satu indikator yang dapat dikatakan memberikan hasil yang maksimal, terdapat pada indikator siswa dapat mencobakan sesuatu dalam kasus sederhana dan tahu bahwa kasus itu berlaku dalam kasus lainnya. Berikut merupakan contoh masalah pemahaman yang diberikan.

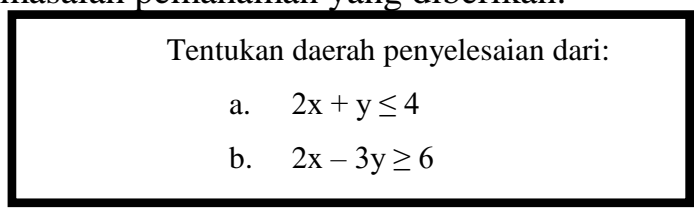

Gambar 1. Contoh Masalah Pemahaman

Berikut hasil pengerjaan siswa.

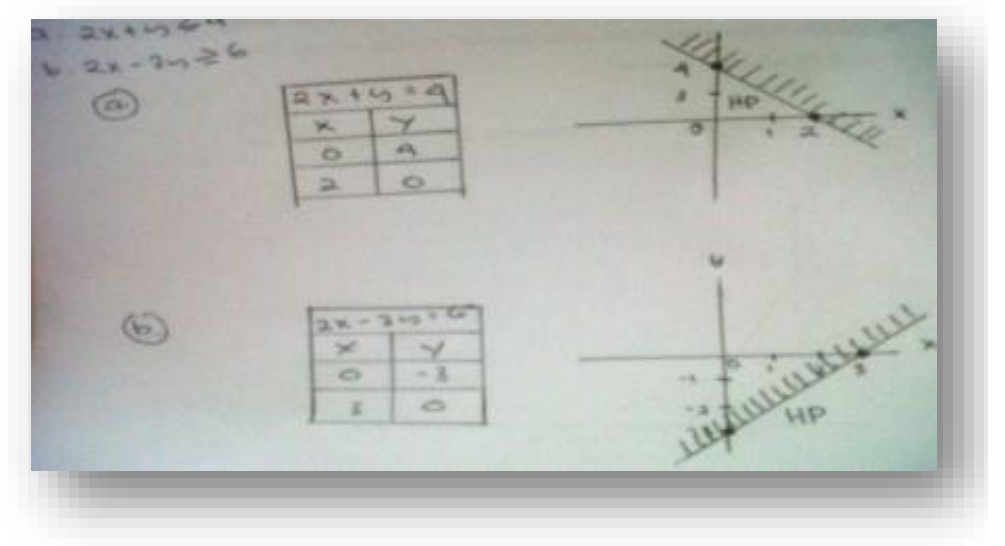

Gambar 2. Hasil Pengerjaan Siswa pada Soal Pemahaman Matematis

Pada indikator ini kedua kelas memiliki hasil rataan postes tertinggi. Namun pembelajaran model Needham memiliki persentase skor 3,83\% lebih tinggi.Analisis data hasil penelitian menunjukkan bahwa kemampuan pemahaman matematis siswa yang belajar dengan pembelajaran konstruktivisme model Needham lebih baik daripada pembelajaran konvensional. Hasil temuan ini mengindikasikan bahwa belajar matematika dengan pembelajaran konstruktivisme model Needham memberikan pengaruh positif terhadap kemampuan pemahaman siswa. Hal ini memberikan gambaran bahwa pembelajaran konstruktivisme model Needham memberikan kontribusi yang baik dalam mengembangkan kemampuan pemahaman matematis siswa.

\section{Peningkatan Kemampuan Komunikasi Matematis}

Berdasarkan analisis data penelitian, terdapat temuan-temuan yang terjadi pada saat penelitian, dimana peningkatan komunikasi matematis siswa yang mendapatkan pembelajaran konstruktivisme model Needham lebih tinggi. Terdapat satu indikator yang 
dikatakan memberikan hasil yang maksimal, terdapat pada indikator mengekspresikan, mendemonstrasikan dan melukiskan ide-ide matematika ke dalam bentuk gambar, table, grafik atau model matematika lain. Berikut merupakan contoh yang diberikan.

PT Bangun Propertindo membangun tiga jenis rumah, yaitu tipe 21, tipe 36, dan tipe 45 di daerah Bandung. Luas tanah yang diperlukan untuk membangun masing-masing tipe berturut-turut adalah $60 \mathrm{~m}^{2}, 72 \mathrm{~m}^{2}$, dan $90 \mathrm{~m}^{2}$ untuk tiap unitnya. Tanah yang

tersedia adalah 50 hektar. $5 \%$ dari luas tanah tersebut digunakan untuk membuat jalan dan fasilitas umum. Rumuskan model matematika yang menyatakan luas tanah dengan banyaknya rumah yang dapat dibangun dari masing-masing tipe.

\section{Gambar 3. Contoh Masalah Komunikasi}

Dari masalah pemahaman di atas siswa diharapkan dapat mengubah persoalan verbal kedalam bentuk model matematika yang merupakan penyejian dalam bahasa sehari-hari ke dalam bahasa matematika yang sebih sederhana dan mudah dimengeri. Berikut hasil pengerjaan siswa.

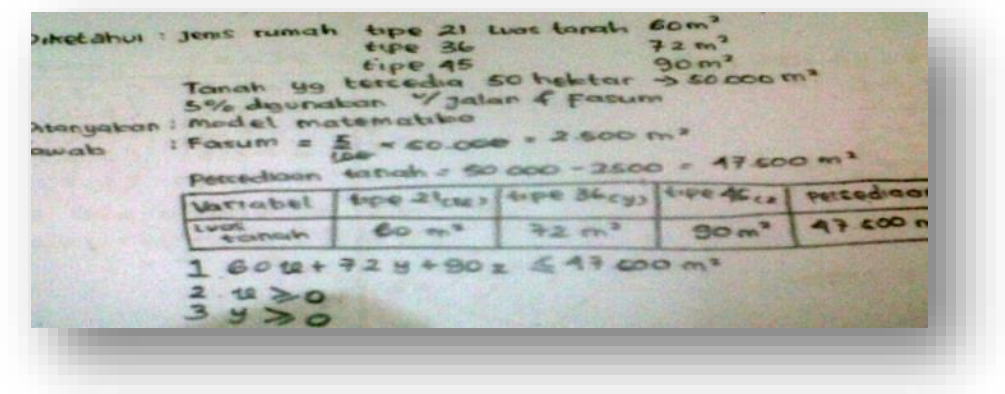

Gambar 4. Hasil pengerjaan Siwa pada Soal Komunikasi Matematis

Berdasarkan hasil pengerjaan siswa di atas terlihat bahwa mampu mengekspresikan, mendemonstrasikan dan melukiskan ide-ide matematika ke dalam model matematika lain. Seperti pembahasan sebelumnya kedua kelas mendapatkan rataan postes tertinggi namun pembelajaran model Needham memiliki persentase skor 8,67\% lebih tinggi dibandingkan dengan pembelajaran konvensional. Analisis data hasil penelitian menunjukkan bahwa kemampuan komunikasi matematis siswa yang belajar dengan pembelajaran konstruktivisme model Needham lebih baik daripada pembelajaran konvensional. Hasil temuan ini mengindikasikan bahwa belajar matematika dengan pembelajaran konstruktivisme model Needham memberikan pengaruh positif terhadap kemampuan komunikasi siswa. Hal ini memberikan gambaran bahwa pembelajaran konstruktivisme model Needham memberikan kontribusi yang baik dalam mengembangkan kemampuan komunikasi matematis siswa.

\section{Sikap Siswa Terhadap Pembelajaran Konstruktivisme Model Needham}

Analisis sikap/respons siswa yang menunjukkan kesukaan siswa terhadap pembelajaran konstruktivisme model Needham. Berdasarkan penyebaran jawaban siswa dari hasil penelitian, dapat diketahui bahwa siswa secara umum cukup merespon dengan positif atau tertarik dengan pembelajaran model Needham, terhadap pelajaran matematika, maupun terhadap soal-soal pemahaman dan komunikasi matematis.

\section{PENUTUP}

1. Peningkatan kemampuan pemahaman matematis siswa yang memperoleh pembelajaran konstruktivisme model Needham secara signifikan lebih baik daripada 
siswa yang memperoleh pembelajaran konvensional, klasifikasi peningkatan kedua kelas masuk pada klasifikasi sedang.

2. Peningkatan kemampuan komunikasi matematis siswa yang memperoleh pembelajaran konstruktivisme model Needham secara signifikan lebih baik daripada siswa yang memperoleh pembelajaran konvensional dengan, klasifikasi peningkatan kedua kelas masuk pada klasifikasi tinggi.

3. Sikap siswa terhadap pembelajaran model Needham dan soal-soal pemahaman an komunikasi matematis menunjukan suatu persetujuan dan minat serta motivasi yang tinggi. Hal ini telihat berdasarkan tanggapan siswa melalui skala sikap yang diperoleh dari hasil temuan bahwa secara umum tanggapan siswa terhadap pembelajaran konstruktivisme model Needham sangat baik.

DAFTAR PUSTAKA

Ansari, B. I. 2003. Menumbuhkembangkan Kemampuan Pemahaman dan Komunikasi Matematis Siswa melalui StrategiThink-Talk-Write. Disertasi pada SPS UPI, Bandung: tidak diterbitkan.

Fitria. 2011. Sikap Belajar Siswa. [Online]. Tersedia: http: //rizcafitria.wordpress.com /2011/04/30/sikap-belajar-peserta-didik/.[10/12/2012]

Hake, R. R. 1999. Analyzing Change/Gain Scores. Tersedia pada http: //www.phsicsIndiana.edu/sdi/AnalyzingChange-Gain.pdf. [13/13/2012].

Nair, S. 2005. Penggunaan model kronstruktivisme lima fasa needham dalam pembelajaran sejarah. Jurnal Pendidik dan Pendidikan, (20), 21-42

NCTM. 2000. Using The NCTM 2000 Principles And Standards With The Learning From Assessment Materials. [online]. Tersedia: http: //www.wested.org/lfa/NCTM2000.PDF. [akses: 8 Oktober 2012].

PISA. 2006. First Result, [online]. Tersedia:

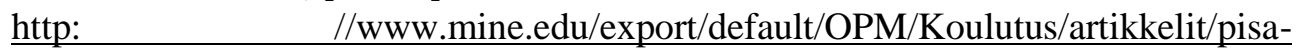
tukkimus/PISA-2006/LIITECT/PISA 2006 en.pdf [05/01/2013]

PISA. 2009. First Result, [online]. Tersedia:

http: //www.moe.gov.sg/media/press/files/2010/annex-pisa-2010.pdf [05/01/2013]

Ruseffendi. 1982. Dasar-Dasar Penelitian Matematika Moderen untuk Guru. Bandung: Tarsito

Sugiyono. 2008. Metode Penelitian Kuantitatif, Kualitatif dan R \& D. Bandung: Penerbit Alfabeta.

Sumarmo, U. 1987. Kemampuan Pemahaman dan Penalaran Matematika Siswa dikaitkan dengan Kemampuan Penalaran Logik Siswa dan Beberapa Unsur Proses Belajar Mengajar. Disertasi PPS UPI. Bandung: tidak diterbitkan.

Sumarmo, U. 2003b. Pembelajaran Matematika untuk Mendukung Pelaksanaan Kurikulum Berbasis Kompetensi. Makalah Pada Pelatihan Guru Matematika, Jurusan Matematika ITB Bandung.

TIMSS. 2011. TIMSS 2011 International Result in Mathematics. Bostom: The International Center Boston College Lynch School of Education. 